\title{
Preface: the legacy of David Unaipon Matthew Rimmer
}

There has been a long history of debate in respect of the use and abuse of Indigenous intellectual property. The story of David Unaipon - storyteller, inventor, scientist, preacher and leader - is important to recall in this narrative.

David Unaipon was the author of the 1930 work The Myths and Legends of Australian Aborigines - later published as Legendary Tales of the Australian Aborigines. ${ }^{1}$ In the Preface to the work, Unaipon discussed his ambitions for the work:

My race - the aborigines of Australia - has a vast tradition of legends, myths and folk-law stories. These, which they delight in telling to the younger members of the tribe, have been handed down orally for thousands of years. In fact, all tribal law and customs are, first of all, told to the children of the tribe in the form of stories, just as the white Australian mother first instructs her children with nursery stories: Of course the mothers and the old men, in telling these stories, drag them out to a great length, putting in every detail, with much gesture and acting, but in writing them down for our white friends I have used the simplest form of expression, in order that neither the meaning nor the 'atmosphere' may be lost. ${ }^{2}$

Unaipon observed: 'As a full-blooded member of my race I think I may claim to be the first - but, I hope not the last - to produce an enduring record of our customs, beliefs and imaginings. ${ }^{3}$ There is a striking sense of collective authorship in this work - David Unaipon brings together an array of stories and tales from a wide range of storytellers.

The book, though, had a troubled literary history. In her 1998 book on the Hindmarsh Island, Dianne Bell recounts the story of the assignment of copyright from David Unaipon to Angus and Robertson, and the publication of his story under the authorship of William Ramsay Smith. She observes of her archival research on the topic:

The Mitchell Library not only holds David Unaipon's manuscript, it also has the correspondence between Ramsay Smith and George Robertson of the publishing house Angus and Robertson (1932). It appears that for 150 pounds, in March 1927, Smith bought the copyright to Unaipon's stories. Unaipon had been paid 'two guineas per 1,000 words' towards two 50,000-word volumes which Angus and Robertson planned to publish. Unaipon had delivered the manuscript by October 1926 but told Smith, whom he had known for some twenty years and whom he had previously approached for assistance in funding his story-collecting travels, that he had heard nothing from the publishers in twelve months. Smith was not prepared to do anything about the material until he clarified how things stood between Unaipon and the publishers. This he did in late 1926. The typescript manuscript was sent to him and by

1 David Unaipon, Legendary Tales of the Australian Aborigines, Melbourne: Melbourne University Press, 2001 (republished, Stephen Muecke and Adam Shoemaker (eds)).

2 Ibid., 3.

3 Ibid., 3. 


\section{xxii Indigenous intellectual property}

September 1927 Smith wrote to Robertson (16/9/1927) of his 'enormous amount of pains-taking work' on the manuscript: 'I think the literary result will prove that it was worth writing.' ${ }^{4}$

Bell noted that in 1930 the work Myths and Legends of the Australian Aboriginals appeared under the authorship of William Ramsay Smith, reproducing the stories of David Unaipon almost word for word. She commented: 'Wherever the truth lies, it is plain that Smith appropriated Unaipon's material.' 5 Bell emphasized: 'There is still the question of moral rights in the material and that needs further attention.' 6

Rhoda Roberts is weary of the constant and incessant appropriation of Indigenous artistic expression and culture by the mainstream white community: 'We're tired of stories being told, not from our perspective, but narrated almost.' ${ }^{7}$ Rhoda Roberts notes that the appropriation of Indigenous artistic expression and culture is nothing new. She recalls that the Aboriginal writer, David Unaipon, wrote a manuscript based on all the stories of his language group in the 1930s, and it was published by Angus \& Robertson under the name of a white author:

David Unaipon was - he's the one on the fifty bucks; if you've got one there - and he's from South Australia, and he wrote in the 30s in fact ... Oodgeroo Noonuccal was really our first published writer, but David Unaipon wrote this manuscript for that Angus \& Robertson - is it George Angus, I think? He was a good mate of David's. David invented the shears for the sheep and when he died they found all these drawings of helicopters based on the aerodynamics of the boomerang and they labelled him the Leonardo of Australia. That was the background. He wrote this manuscript based on all the stories of his language group, gave them over, which were then given to a guy and his last name was Brown who published a book in 1938, word for word, of David Unaipon. You can pick up that book and go, 'Oh great, creation stories from days gone by. I'll read that, oh that's gospel.' Well it is, but [...]. So constantly you're fighting that level of control of the product. ${ }^{8}$

Rhoda Roberts has been worried about contemporary developments in terms of the appropriation of Indigenous intellectual property. She was keen to ensure that Indigenous people should retain control over their work.

In terms of the publishing history of the work, Stephen Muecke and Adam Shoemaker lament that successive editions of the text also failed to attribute the original author, David Unaipon. ${ }^{9}$ The writers comment that 'David Unaipon was totally erased from the work; the only indirect nod towards the true author appears in the preface of the Harrap edition'. ${ }^{10}$ Muecke and Shoemaker reflected that the lack of attribution continued from editions in the 1930s to 2000: 'Throughout all these years,

4 Diane Bell, Ngarrindjeri Wurruwarrin: A World That Is, Was, and Will Be, Melbourne: Spinifex, 1998, 130-131.

5 Ibid.

6 Ibid.

7 Rhoda Roberts, 'A Passion for Ideas: Black Stage' (1998) 32 Australasian Drama Studies 3.

8 Ibid.

9 David Unaipon, Legendary Tales of the Australian Aborigines, Melbourne: Melbourne University Press, 2001 (republished, Stephen Muecke and Adam Shoemaker (eds)).

10 Ibid., Xxxviii. 
these most Australian of stories were never published in their country of origin, nor with due acknowledgment given to their true creator.' 11

At the original time of the controversy over David Unaipon's lack of attribution, there would have been little in the way of legal protection under Australian copyright law. For a long period of its history, Australia only provided for recognition of economic rights. It took a sustained campaign by Australian creative artists over many decades to win the introduction of moral rights. ${ }^{12}$ It is worth noting that Australia did not provide full recognition of moral rights under copyright until 2000. ${ }^{13}$ There has been some litigation over the moral right of attribution and the moral right against false attribution. ${ }^{14}$ There has also been significant litigation over the moral right of integrity. ${ }^{15}$ There have also been a number of settlements in the shadow of the moral rights regime - particularly in architecture. ${ }^{16}$ However, there has been a failure to address communal ownership of Indigenous cultural works in Australia - both in terms of economic rights and moral rights. ${ }^{17}$

There has, though, been a strong case made that copyright ownership has reverted back to David Unaipon's heirs and relatives. Stephen Muecke and Adam Shoemaker have highlighted questions of copyright ownership and duration:

William Ramsay Smith died in 1937. This means that copyright in his published version (the 1930 Harrap book) has lapsed. But the more pertinent copyright issue is this: if - as we now know - the original author of the entire book was David Unaipon then, according to both Australian and British law in force at the time of first publication in 1930, twenty-five years after the death of the original creator the copyright reverts to Unaipon's heirs and successors, regardless of any assignments made during his lifetime. Since Unaipon died in 1967 the crucial date for the assertion of intellectual property rights becomes $1992 .{ }^{18}$

11 Ibid., xxxix.

12 Matthew Rimmer, 'Daubism: Copyright Law and Artistic Works' (2002) 9(4) Murdoch University Electronic Journal of Law, SSRN: http://papers.ssrn.com/sol3/papers.cfm?abstract_ $\mathrm{id}=600864$

13 Copyright Amendment (Moral Rights) Act 2000 (Cth). For a commentary on the regime, see Maree Sainsbury, Moral Rights and their Application in Australia, Sydney: The Federation Press, 2003; and Elizabeth Adeney, The Moral Rights of Authors and Performers: An International and Comparative Analysis, Oxford: Oxford University Press, 2006, 149.

14 Meskenas v. ACP Publishing Pty Ltd [2006] FMCA 1136 (14 August 2006).

15 Perez \& Ors v. Fernandez [2012] FMCA 2 (10 February 2012).

16 Matthew Rimmer, 'Crystal Palaces: Copyright Law and Public Architecture' (2002) 14(2) Bond Law Review 320-346; and Matthew Rimmer, 'The Garden of Australian Dreams: The Moral Rights of Landscape Artists' in Fiona MacMillan, and Kathy Bowrey (eds) New Directions in Copyright Law: Volume 3. Cheltenham (UK) and Northampton (MA): Edward Elgar Publishing, 2006, pp. 132-168.

17 See, for instance, the debate over the Copyright Amendment (Indigenous Communal Moral Rights) Bill 2003 (Cth), which was never passed.

18 David Unaipon, Legendary Tales of the Australian Aborigines, Melbourne: Melbourne University Press, 2001 (republished, Stephen Muecke and Adam Shoemaker (eds)), xxxix. 
After consultation with lawyers, Muecke and Shoemaker concluded that "'a substantial portion" of Unaipon's manuscript was reproduced by Ramsay Smith and that intellectual and moral rights to the work reside with the David Unaipon Estate'. ${ }^{19}$

In 2001, literary scholars, Stephen Muecke and Adam Shoemaker sought to engage in literary repatriation, and republish the work under the authorship of David Unaipon. ${ }^{20}$ The pair worked with the nominee of the Unaipon estate, Unaipon's great-niece, Melva Kropinyeri, and her children, including Harold Kym. The two academics explained their approach to the restoration work:

Literary repatriation involves restoring the text to a form as close as possible to the original handwritten manuscript. But it also involves weaving the text back home to the community (or communities or family groups) where the stories were told and traded in the first place. This is why David Unaipon's descendants (especially Harold [Kym] Kropinyeri and his sisters Judy and Elaine) have been involved in checking the manuscript for anything that is inconsistent according to their knowledge, and restoring the occasional word that was lost in the transcription from Unaipon's handwritten version to the typescript. ${ }^{21}$

Muecke and Shoemaker commented that it is our hope that literary repatriation will point to the place-specific relevance of writing'. ${ }^{22}$ The editors noted that 'such works intensify their meanings if they are seen to be rooted in a series of places'. ${ }^{23}$ Muecke and Shoemaker contended that literary repatriation is 'a decolonising gesture for literature, it turns away from the imperialism and universalism of writing that is supposed to transcend place, aspire to the universal, and conquer time by becoming of permanent historical significance' ${ }^{24}$

In addition to battles over the literary works of David Unaipon, there has also been significant conflict over the personality rights of David Unaipon - particularly since he has been featured on Australian currency. The Reserve Bank of Australia has been involved in a number of intellectual property conflicts over the use of Indigenous imagery over the years. ${ }^{25}$ The Reserve Bank of Australia introduced new polymer currency notes in 1988. ${ }^{26}$ In 1995, the Reserve Bank of Australia released a \$50 note, designed by Brian Sadgrove, featuring David Unaipon and Edith Cowan. The Reserve Bank noted in its history:

19 Ibid., xxxix.

20 David Unaipon, Legendary Tales of the Australian Aborigines, Melbourne: Melbourne University Press, 2001 (republished, Stephen Muecke and Adam Shoemaker (eds).

21 Ibid., xliii.

22 Ibid., xliii.

23 Ibid., xliii.

24 Ibid., xliii.

25 See Terri Janke, Beyond Guarding Ground - A Vision for a National Indigenous Cultural Authority, Sydney: Terri Janke \& Co, 2009, http://2014.australiacouncil.gov.au/resources/ reports_and_publications/subjects/policy/beyondguardingground/Beyond_guarding_ground.pdf

26 The Reserve Bank of Australia, 'A New Era - Polymer Currency Notes: 1988 Onwards', http://www.rba.gov.au/Museum/Displays/1988_onwards_polymer_currency_notes/complete_series. html 
David Unaipon (1872-1967), a South Australian writer, inventor and public speaker, was an impressive spokesman for the Aboriginal people. He was the first Aboriginal author to be published. An extract from his story Legendary Tales of the Australian Aborigine features on the $\$ 50$ note. $^{27}$

The work features a handwritten Preface to 'Legendary Tales of the Australian Aborigine' - which is credited to the State Library of New South Wales. The $\$ 50$ note also features a diagram for a patent application by David Unaipon for a circular shearing device.

The family of David Unaipon has complained about his representation on the $\$ 50$ note by the Reserve Bank. ${ }^{28}$ In 2008, Allan 'Chirpy' Campbell - the great-nephew of David Unaipon - demanded the Reserve Bank of Australia pay damages to his family for using Unaipon's image on the $\$ 50$ note without permission. He alleged that permission to use the Indigenous inventor and author's image was given by someone posing as a relative. As well as seeking a 'fair dinkum settlement' Campbell put a further three demands to the Reserve Bank:

My lawyer has got to be paid for 10 years' work. I want them to pay for the damages for what they put upon us and we want a re-enactment of the celebration of the $\$ 50$ note $\ldots$ in Adelaide. If they had of got the Mundine family or Cathy Freeman ... they would have also had to be forking out an arm and a leg for them, therefore this has got to be renegotiated. And then we'll give them permission for him to remain on the $\$ 50$ note. ${ }^{29}$

Campbell sought \$30 million dollars from the Reserve Bank of Australia for the unauthorised use of Unaipon's image. ${ }^{30}$ The Reserve Bank of Australia denied the compensation request. ${ }^{31}$

The family of David Unaipon also objected to the use of images of David Unaipon on advertisements by PayPal, the online payments service owned by eBay. ${ }^{32}$ The advertising campaign on the sides of buses featured images of the $\$ 10, \$ 20, \$ 50$ and $\$ 100$ bank notes, with police and military helmets superimposed on each of the portraits. The campaign was intended to emphasise that PayPal provided enhanced safety and fraud protection for its users. Allan Campbell complained: 'It is very disrespectful because for a start no Aboriginal people have a helmet - we're not bikies and we're not Vikings.' ${ }^{33}$ His brother, John Campbell, observed that PayPal should have contacted his family first to ask for permission to use the image. He commented that

27 Ibid.

28 The Daily Telegraph, 'Family Demands Payout for $\$ 50$ Note Image of David Unaipon', The Daily Telegraph, 28 November 2008, http://www.dailytelegraph.com.au/family-demandspayout-for-50-note-image-of-david-unaipon/story-e6freuy9-1111118166149

29 Ibid.

30 Tom Arup, '\$30 Million Claim is All About Face’, The Age, 28 November 2008.

31 ABC News, 'Compensation Bid for "\$50 Note Nephew" Denied', ABC News, 27 November 2008, http://www.abc.net.au/news/2008-11-27/compensation-bid-for-50-note-nephewdenied/221492

32 Asher Moses, "Take Note PayPal, Cashing In on a Legend is "Degrading", The Age, 2 December 2008, http://www.theage.com.au/articles/2008/12/02/1227980000056.html

33 Ibid. 
the family would not have agreed to let PayPal use the image in such a 'degrading' and 'disrespectful' way. ${ }^{34}$

There have been somewhat more respectful representations of the life and work of David Unaipon. In 2004, Bangarra Dance Theatre produced a work called Unaipon. ${ }^{35}$ The Indigenous dance company has been innovative, not only its engagement with Indigenous cultural forms in Australia, but also in matters of intellectual property. Bangarra Dance Theatre discussed the production on the 7:30 Report on the ABC. The choreographer, Frances Rings, commented that the work was about her passion for science, philosophy, writing, the rights of her people, and religion. She reflected upon the character of David Unaipon:

I think he was a very tenacious man. He walked in a country that - it was an indomitable landscape. Not many people had, you know, walked that line between the two worlds. It would have been a really difficult time for him. I think he was just blessed with just having a strong spirit. ${ }^{36}$

Stephen Page, the artistic director, observed: 'Even though, you know, Mr Unaipon is on our $\$ 50$ note, it wasn't part of my history at school.' ${ }^{37} \mathrm{He}$ hoped that the work would encourage a greater awareness of the life and work of David Unaipon: 'And so, I think, this just really consciously awakens this awareness of great Australians, but also a great Indigenous leader.' 38

In addition to being involved in battles over copyright law and literary works, and disputes over personality rights, David Unaipon also features as a significant figure in the history of Australian patent law. Unaipon was known as a 'scientist lecturer'. He was particularly interested in mechanics, polarised light and perpetual motion. Notably, Unaipon developed and lodged a patent application for a handpiece for shearing. ${ }^{39}$ The patent application specified a 'straight line motion for sheep shears, \&c.: a sliding and reciprocating arm co-acts with cam surface is pivotally connected to moving cutter running in straight tenon'. ${ }^{40}$ Stephen Muecke and Adam Shoemaker commented: 'In all, from 1910 to 1944 he made ten separate applications for inventions as varied as an anti-gravitational device, a multi-radial wheel and a sheep-shearing handpiece.' ${ }^{41}$

34 Ibid.

35 Bangarra Dance Theatre, Unaipon, http://www.bangarra.com.au/performance/clan. For a further discussion of the work of Bangarra Dance Theatre, see Matthew Rimmer, 'Bangarra Dance Theatre: Copyright Law and Indigenous Culture' (2000) 9(2) Griffith Law Review 274-302, and Stephen Page and Greg Barrett, Clan, Sydney: Allen and Unwin, 2013.

36 Kathy Swan, 'David Unaipon Inspires Theatre Production', 7:30 Report, ABC News, 14 June 2015, http://www.abc.net.au/7.30/content/2004/s1131623.htm

37 Ibid.

38 Ibid.

39 David Unaipon, 'Patent Specification. Mechanical Motion. Sheep Shears', Australian Patent Application No. 15,624, Melbourne: Government Printer, 1910, http://www.slsa.sa.gov.au/ murray/content/didyouknow/Unaipon.htm

40 Ibid.

41 David Unaipon, Legendary Tales of the Australian Aborigines, Melbourne: Melbourne University Press, 2001 (republished, Stephen Muecke and Adam Shoemaker (eds), xv. 
Virginia Marshall, Terry Janke and Anthony Watson observed of the patent applications: 'This indicates that the value of patent registration was recognised as paramount to protecting an inventor's right, both for Aboriginal and non-Aboriginal people.' ${ }^{2}$ Unfortunately, David Unaipon lacked the funds to sustain his patent applications, and they lapsed. His situation highlights larger questions about access to justice, particularly in respect of the registration schemes of intellectual property. Such complications are elided in official storytelling. In its popular history of Australian inventions, the Australian Government lauded David Unaipon as 'Australia's Leonardo' for his promotion of scientific ideas. ${ }^{43}$

The historical case of David Unaipon is a good starting point for a wider discussion of Indigenous intellectual property law, practice and reform. His story is a microcosm of larger battles over the cultural appropriation of Indigenous culture, iconography and science. David Unaipon could be seen as a beneficiary of intellectual property law. He is a creator of copyright works; an inventor of patented inventions; and an iconic figure, worthy of personality rights. His creative and scientific work has been an inspiration for others. David Unaipon could also be seen as being disenfranchised by intellectual property law. He lost ownership of his economic rights in respect of literary works; and his moral rights have not been respected under copyright law. His case also highlights the deficiencies of copyright law in respect of its failure to provide comprehensive recognition of communal authorship and ownership of copyright works. While he was a patent applicant, David Unaipon never seemed to have benefitted from the patent system. His experience raises questions about access to justice. The government and commercial use of the persona of David Unaipon raises complex questions about trade mark law, passing off and personality rights. The story of David Unaipon highlights the need for the systematic and holistic reformation of intellectual property law, so that it better serves Indigenous communities and peoples.

42 Virginia Marshall, Terri Janke and Anthony Watson, 'Community Economic Development in Patenting Traditional Knowledge: A Case Study of the Mudja la TK Project in the Kimberley Region of Western Australia' (2013) 8(6) Indigenous Law Bulletin 17-21.

43 Australian Government, 'Australian Inventions', http://australia.gov.au/about-australia/ australian-story/austn-inventions 
Matthew Rimmer - 9781781955901 